\title{
STRUCTURE OF THE DALDYN FIELD (YAKUTIAN PROVINCE) BASED ON THE STUDY OF PICROILMENITE COMPOSITION
}

\author{
By S.I. Kostrovitsky ${ }^{1}$, N.V. Alymova ${ }^{1}$, A.S. Ivanov $^{2}$, V.P. Serov ${ }^{2}$ \\ 1 - Institute of Geochemistry, Irkutsk, Russia; ${ }^{2}$ Almazy Rossii-Sakha Co. Ltd. Mirny, Yakutia, Russia
}

The taxonomic units of kimberlite volcanism are: province, kimberlite field, cluster of pipes, pipe, dyke and sill. The taxons are recognized with only geographic principle in view: spatial proximity of kimberlite bodies and spatial separated location of each taxon. Numerous attempts to define the relationship of structure with tectonics were not successful.

\section{PROBLEMS OF KIMBERLITE TAXONS ANALYSIS}

The question arises whether each geographic taxon of kimberlite volcanism carries a certain genetic inheritance. This primarily concerns the relationship between the bodies of pipes united in a taxon, which is the case due to the activity of the same magmatic chamber. However it is still a point of argument if the magmatic chamber was the same in a pipe only, or in a cluster of pipes, or in the entire field. The objective of our study is to decide this question, what it's necessary for the understanding of genetic models of cluster and field pipes.

The goal of revealing the primary magmatic component was most difficult to be approached. Kimberlites represent heterogeneous rocks containing mineral xenocrysts, xenoliths of mantle rocks, rocks of crystalline basement and sedimentary cover, which underwent intense hydrothermal and metasomatic reworking. Some researchers assume that the factors causing transformation of primary composition are so severe that its reduction is not feasible. In our opinion, because of isochemical processes occurring in most metasomatic processes a series of mostly inert petrogenic oxides and microelements retain information on the primary composition of kimberlites. These are TiO2, $\mathrm{Al}_{2} \mathrm{O}_{3}\left(\right.$ ?), $\mathrm{FeO}, \mathrm{MnO}, \mathrm{K} 2 \mathrm{O}, \mathrm{P}_{2} \mathrm{O}_{5}, \mathrm{Zr}, \mathrm{Nb}$.

\section{ROLE OF MINERALS IN THE ANALYSIS OF KIMBERLITE TAXONS}

The most widespread minerals of a heavy fraction of kimberlites are picroilmenite, garnet; infrequently occurring are chrome-spinel, chrome-diopside, olivine, apatite and phlogopite. Sparse occurrence of most minerals drastically reduce information relative to the genesis of larger taxons than the pipe itself. Out of proto-minerals only the majority of olivine and picroilmenite have phenocryst nature. As regards garnet, its dominant part has xenogenic origin. The genetic inheritance of the two minerals olivine and picroilmenite is described below. Olivine, being the rock-forming mineral, occurs in kimberlite pipes as relict. Only in some pipes (Udachnaya-vostochna) it is preserved as large amounts. Olivine is characterized by a high magnesian content, and its composition lies within interval $6-14 \mathrm{~mol} \%$ of phayalite minal. The phenocrysts of olivine from different pipes demonstrate different variations of the composition. In the Daldyn field the pipes are filled with kimberlite which basically contains: (1) highly-magnesian olivine (pipes Osennyaya, Zimnyaya, Aeros'emochna); (2) more ferrous olivine (pipes Polyarna and Festivalna); (3) olivine with a wide range of composition (pipes Udachnaya, Zarnitsa). Remarkably, that in intricately built multi-phase pipes (Udachnaya-eastern, Mir, Aikhal) the ratio of highly magnesian and relatively ferruginous olivine is a steady value only within one phase of intrusion, and it widely varies from phase to phase. For example, in the pipe Udachnaya-vostochna it was found (Kostrovitsky, 1986), that initial stages of intrusion are enriched in relatively ferruginous olivine, and the final phases primarily consist of highlymagnesian olivine. Because olivine in kimberlites is generally not retained due to serpentinization only picroilmenite is left. It may be studied as regards inhomogeneity of primary composition of kimberlites within one cluster or a field of pipes.

A widespread occurrence, high contents, stability in exogenic processes of kimberlite destruction and formation of diamond collectors point out significance of picroilmenite in prospecting, mineralogical mapping and solution of genetic problems. Picroilmenite is typified by a wide spectrum of compositions. On a triangular diagram of minals $\mathrm{FeTiO}_{3}-\mathrm{MgTiO}_{3}-\mathrm{Fe}_{2} \mathrm{O}_{3}$ ilmenites form continuous fields of compositions (trends) mainly on account of ilmenite and geikielite minals. The kimberlite fields commonly differ from each other in the composition of picroilmenite. For example, only kimberlites of the Malo-Botuoba field contain abundant ferri-magnetic ilmenite with a high hematite minal. Ilmenites of the Alakit field on average contain more chrome than ilmenites of the Daldyn field. Ilmenites of the Ogon'or and Motorchunsky, NizhneUkukit and Luchakan fields are high in magnesium. 


\section{THE DALDYN FIELD STRUCTURE}

Over 60 pipe, dyke and vein bodies have been discovered within the Daldyn field. The majority of kimberlite pipes are grouped into clusters (Fig. 1), in places extending linearly, with the distance between pipes ranging from few hundred meters to $1-2 \mathrm{~km}$. The distance between clusters of pipes varies from one to few kilometers. Within the same field the pipes occur irregularly. The northern part (mainly the left bank of the Daldyn river) rich in kimberlite bodies displays chaotic pattern of their location. Thus, it is sometimes hard to distinguish individual pipe clusters. In the southern part of the field (the right bank of the Daldyn river) they are recognized clearly, for they lie separately and commonly show linear extension.

The first researcher, who attracted petrochemical and mineralogical characteristics for interpreting the structure of the field was I.P.Ilupin (Ilupin et al., 1976, 1990). The author suggested a concentric geochemical zonation of the Daldyn field. He believes that kimberlites of the central part of the field are moderately enriched in $\mathrm{Mn}, \mathrm{Co}, \mathrm{Ni}$ and $\mathrm{Ga}$, and kimberlites of the marginal zone are rich in alkaline metals, $\mathrm{Ba}$ and P. In our view (Kostrovitsky, 1986), in the Daldyn field the distribution of petrogenic oxides $\left(\mathrm{TiO}_{2}, \mathrm{FeO}\right)$, and such a mineralogical parameter as the ratio of weight amounts in kimberlite of picroilmenite to garnet reflects a linear zonation of submeridional trend. The kimberlites of clusters occurring in the central zone, e.g. clusters Polyarna, Aeromagnitna, Yakutska and Dalnya, are marked by maximum iron and titanium coefficients, predominance of weight of picroilmenite over pyrope, maximum content of violet and crimson garnet. The problem of preference of either linear-zonal or concentrically-zonal model to a real mineralogical and perochemical structure of the Daldyn field requires supplementary studies.

\section{DISTRIBUTION OF THE ILMENITE COMPOSITION IN THE DALDYN FIELD}

The composition of picroilmenite from the pipes of all clusters of the Daldyn field of the Yakutian province was studied in detail (Fig. 2). The map displays only the northern part of the field distinguished by the most abundant clustering of pipes. The microprobe analysis was performed in the Central Analytical laboratory of the "ALROSA" Corporation by "Superprobe JXA 8800R" "GEOL".

Table 1 lists averaged data on the most representative oxides of picroilmenite composition $\mathrm{MgO}, \mathrm{Cr}_{2} \mathrm{O}_{3}$ and $\mathrm{FeO}_{\text {total }}$ for all pipes and clusters of the Daldyn field, which contain this mineral. It is evident that ilmenite

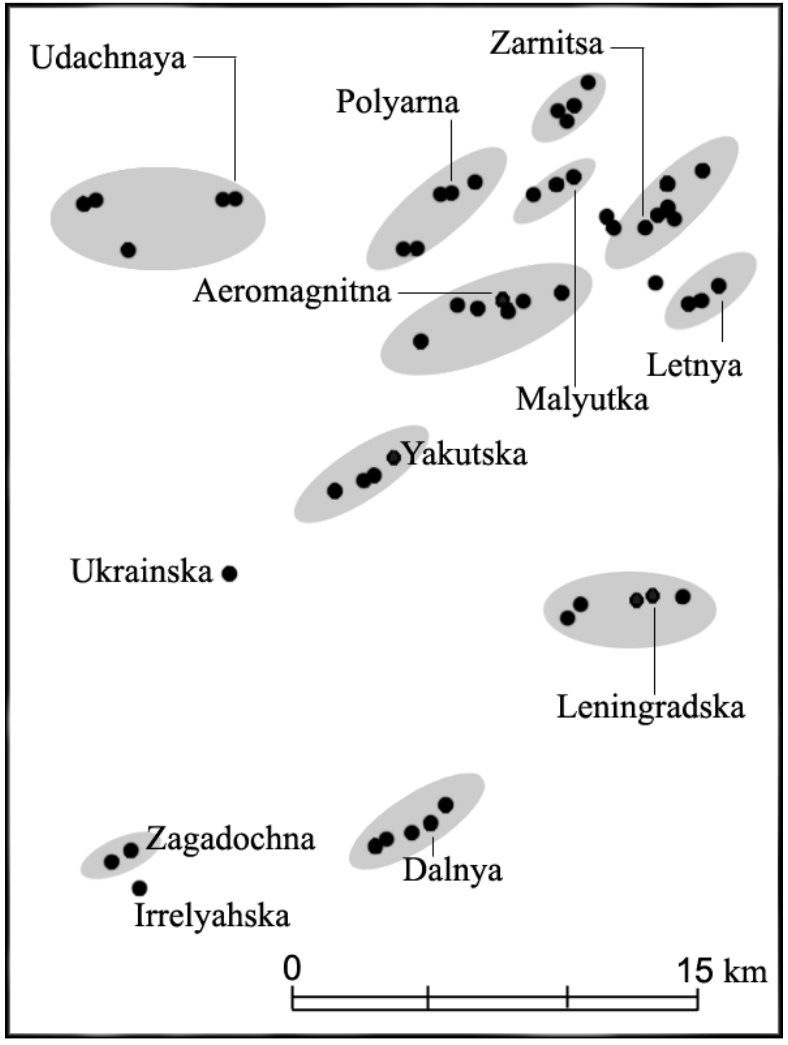

Figure 1. Map of pipe location of the Daldyn kimberlite field (Yakutian province) with the names of the main pipes of clusters shown as darkened ovals.

from different clusters shows essential differences in one of the parameters indicated, while ilmenite from different pipes of the same cluster is characterized by close values of the above parameters. For example, the ilmenite from clusters of pipes Aeromagnitna and Dalnya has close values of $\mathrm{Cr}_{2} \mathrm{O}_{3}$, but considerably differs in $\mathrm{MgO}$ and so on. However, some clusters include rare pipes with the compositions differing from the rest. The pipes proximal in a cluster have similar compositions. For example, in the cluster of pipe Yakutskaya a high similarity between each other is shown by proximal pipes Academic and Aeros'emochna on the one hand, and Yakutska and Ilmenitova, on the other hand. In the cluster of pipe Polyarna, proximal are Volzhanka and Lubima, and Polyarna and Studencheska. The pipes which contain picroilmenite, significantly different in composition from other cluster pipes, are exceptionally rare. Such pipes commonly occur in a cluster sitting aside from the linear chain of pipes. These exceptions are made by pipe Vesnushka (cluster Aeromagnetic), pipes Altayska and Makatoyska (cluster Zarnitsa), pipe Festivalnaya (cluster Polayarna) and pipe Irrelyakhska (cluster Zagadochna). 


\section{Table 1. The average composition of} picroilmenite from the Daldyn field

\begin{tabular}{|c|c|c|c|c|c|c|}
\hline \multirow{2}{*}{\begin{tabular}{|l|}
$\begin{array}{l}\text { Cluster of } \\
\text { pipes }\end{array}$ \\
\end{tabular}} & \multirow{2}{*}{ Pipe } & \multirow[t]{2}{*}{$\mathrm{N}$} & \multicolumn{4}{|c|}{ Average composition } \\
\hline & & & $\mathrm{Cr}_{2} \mathrm{O}_{3}$ & $\mathrm{MgO}$ & FeOtot & $\mathrm{Mg} \#$ \\
\hline \multirow[t]{6}{*}{$\begin{array}{l}\text { Aeromag } \\
\text { nitna }\end{array}$} & $\begin{array}{l}\text { Aeromag } \\
\text { nitna }\end{array}$ & 108 & 0,97 & 9,67 & 39,28 & 19,9 \\
\hline & Endir & 73 & 0,82 & 9,35 & 40,07 & 19,05 \\
\hline & Evrika & 84 & 0,82 & 9,2 & 39,98 & 18,89 \\
\hline & Mastahska & 105 & 0,85 & 9,1 & 39,85 & 18,87 \\
\hline & $\begin{array}{l}\text { Aeromag- } \\
\text { nitna* }\end{array}$ & 370 & 0,87 & 9,34 & 39,75 & 19,21 \\
\hline & Vesnushka** & 30 & 1,22 & 8,4 & 39,01 & 18,03 \\
\hline \multirow[t]{8}{*}{ Dalnya } & Dalnya & 82 & 0,8 & 10,9 & 36,41 & 23,05 \\
\hline & Jila-70 & 71 & 0,84 & 11,6 & 35,46 & 24,73 \\
\hline & Jila-74 & 66 & 0,86 & 11,2 & 35,54 & 23,95 \\
\hline & Mambo & 110 & 0,84 & 10,7 & 36,79 & 22,63 \\
\hline & Nu-pogodi & 78 & 0,8 & 11 & 36,94 & 23,06 \\
\hline & Saratovska & 101 & 0,77 & 11,3 & 36,38 & 23,71 \\
\hline & Ugadayka & 79 & 0,85 & 10,9 & 36,79 & 23,03 \\
\hline & Dalnya & 587 & 0,82 & 11,1 & 36,39 & 23,39 \\
\hline \multirow[t]{4}{*}{ Malutka } & Malutka & 92 & 1,71 & 8,82 & 41,16 & 17,67 \\
\hline & Sosednya & 89 & 1,45 & 9,05 & 41,08 & 18,07 \\
\hline & Daykova & 93 & 1,74 & 8,7 & 39,66 & 18,04 \\
\hline & Malutka & 276 & 1,63 & 8,82 & 40,48 & 17,9 \\
\hline \multirow{3}{*}{$\begin{array}{l}\text { Rot- } \\
\text { Front }\end{array}$} & Овал & 127 & 1,18 & 11,1 & 35,46 & 23,78 \\
\hline & Rot-Front & 83 & 1,2 & 10,3 & 37,92 & 21,43 \\
\hline & Rot-Front & 210 & 1,19 & 10,7 & 36,69 & 22,6 \\
\hline \multirow[t]{5}{*}{ Udachna } & $\begin{array}{l}\text { Udachna- } \\
\text { vost }\end{array}$ & 82 & 1,01 & 9,6 & 39,92 & 19,46 \\
\hline & Udachna-zap & 88 & 1,2 & 9,07 & 40,28 & 18,42 \\
\hline & Polunochna & 12 & 0,74 & 9,27 & 33,75 & 24,99 \\
\hline & Sibirska & 3 & 0,8 & 9 & 40,96 & 18,4 \\
\hline & Udachna & 185 & 1,09 & 9,31 & 40,04 & 19 \\
\hline \multirow[t]{6}{*}{ Yakutska } & $\begin{array}{l}\text { Akademiche } \\
\text { ska }\end{array}$ & 122 & 0,9 & 9,79 & 37,44 & 20,72 \\
\hline & $\begin{array}{l}\text { Aeros'emo } \\
\text { chna }\end{array}$ & 79 & 1,06 & 9,33 & 38,33 & 19,65 \\
\hline & Ilmenitova & 111 & 0,86 & 9,91 & 38,43 & 21,04 \\
\hline & Yakutska & 85 & 0,74 & 9,15 & 38,21 & 19,40 \\
\hline & Yakutska & 397 & 0,89 & 9,60 & 38,06 & 20,3 \\
\hline & Ukrainska & 99 & 1,28 & 9,49 & 38,74 & 19,76 \\
\hline
\end{tabular}

The histograms of $\mathrm{Cr}_{2} \mathrm{O}_{3}$ and $\mathrm{MgO}$ distribution in different pipes obtained while analyzing the composition of ilmenite are of particular interest. Their types: (1) single peak with a normal pattern of distribution, e.g. pipes of cluster Dalnyaya (Fig. 2), Leningradska;

\begin{tabular}{|c|c|c|c|c|c|c|}
\hline \multirow{2}{*}{\begin{tabular}{|l|} 
Cluster \\
of pipes \\
\end{tabular}} & \multirow[t]{2}{*}{ Pipe } & \multirow[t]{2}{*}{$\mathrm{N}$} & \multicolumn{4}{|c|}{ Average composition } \\
\hline & & & $\mathrm{Cr}_{2} \mathrm{O}_{3}$ & $\mathrm{MgO}$ & FeOtot & $\mathrm{Mg} \#$ \\
\hline \multirow{6}{*}{$\begin{array}{l}\text { Polyar- } \\
\text { na }\end{array}$} & Volzhanka & 97 & 0,82 & 9,29 & 40,41 & 18,79 \\
\hline & Lubima & 124 & 0,84 & 9,3 & 39,56 & 19,05 \\
\hline & Polyarna & 92 & 0,74 & 9,98 & 38,85 & 20,53 \\
\hline & Studenchesk & 91 & 0,76 & 9,58 & 39,71 & 19,48 \\
\hline & Polyarna & 404 & 0,79 & 9,54 & 39,45 & 19,52 \\
\hline & Festivalna & 10 & 1,49 & 10,6 & 37,34 & 22,20 \\
\hline \multirow[t]{5}{*}{ Letnya } & Zimnya & 85 & 1,55 & 8,21 & 40,52 & 17,11 \\
\hline & Letnya & 87 & 1,56 & 8,67 & 40,45 & 17,74 \\
\hline & Osennya & 64 & 1,81 & 8,48 & 40,20 & 17,51 \\
\hline & Letnya & 236 & 1,62 & 8,45 & 40,41 & 17,5 \\
\hline & Prognozna & 99 & 0,7 & 10,1 & 37,04 & 21,37 \\
\hline \multirow{4}{*}{$\begin{array}{l}\text { Zagado } \\
\text { chna }\end{array}$} & Zagadochna & 34 & 0,71 & 9,11 & 39,62 & 19,3 \\
\hline & Kusova & 2 & 0,87 & 9,77 & 41,61 & 19 \\
\hline & Zagadochna & 36 & 0,72 & 9,15 & 39,73 & 19,2 \\
\hline & Irrelyahska & 11 & 1,01 & 10,1 & 38,45 & 21,1 \\
\hline \multirow[t]{10}{*}{ Zarnitca } & Elektra & 105 & 0,97 & 9,2 & 40,52 & 18,63 \\
\hline & Argis & 100 & 1,01 & 8,98 & 40,35 & 18,34 \\
\hline & Nevedimka & 95 & 0,85 & 8,99 & 39,92 & 18,27 \\
\hline & Iksova & 123 & 0,93 & 9,22 & 40,64 & 18,04 \\
\hline & Zarnitsa & 114 & 0,94 & 8,96 & 40,66 & 18,16 \\
\hline & Popugaevoy & 116 & 0,93 & 8,84 & 40,92 & 17,95 \\
\hline & Cheburashka & 30 & 1,16 & 8,35 & 41,82 & 16,66 \\
\hline & Zarnitsa & 683 & 0,95 & 9,00 & 40,59 & 18,2 \\
\hline & Altayska & 98 & 0,51 & 9 & 40,59 & 18,21 \\
\hline & Makatoyska & 90 & 0,79 & 9,31 & 40,06 & 18,93 \\
\hline \multirow{6}{*}{$\begin{array}{l}\text { Leningr } \\
\text { adska }\end{array}$} & Molodezna & 80 & 0,73 & 10,8 & 35,62 & 23,37 \\
\hline & Leningradsk & 90 & 0,77 & 11,1 & 34,73 & 24,41 \\
\hline & $\begin{array}{l}\text { Geophisiche } \\
\text { ska }\end{array}$ & 37 & 0,74 & 12 & 34,09 & 25,98 \\
\hline & Dolgozdana & 105 & 1,1 & 10,8 & 36,51 & 22,90 \\
\hline & Nurbinska & 111 & 0,93 & 10,3 & 37,11 & 21,76 \\
\hline & $\begin{array}{l}\text { Leningrads } \\
\text { ka }\end{array}$ & 423 & 0,87 & 10,7 & 35,41 & 23 \\
\hline
\end{tabular}

$\mathrm{N}=$ number of grains, $*$ - cluster of pipes, $* *$ - individual pipes, which contain ilmenite of different composition.

(2) two-peak (pipes of clusters Yakutska, Rot-Front after $\mathrm{MgO}$ ); (3) three-peak with clear minima dividing all ilmenites under analysis into three groups (e.g. pipes of clusters Zarnitsa (Fig. 2) and Malyutka). The $1^{\text {st }}$ and $3^{\text {rd }}$ types of histograms are most common. 

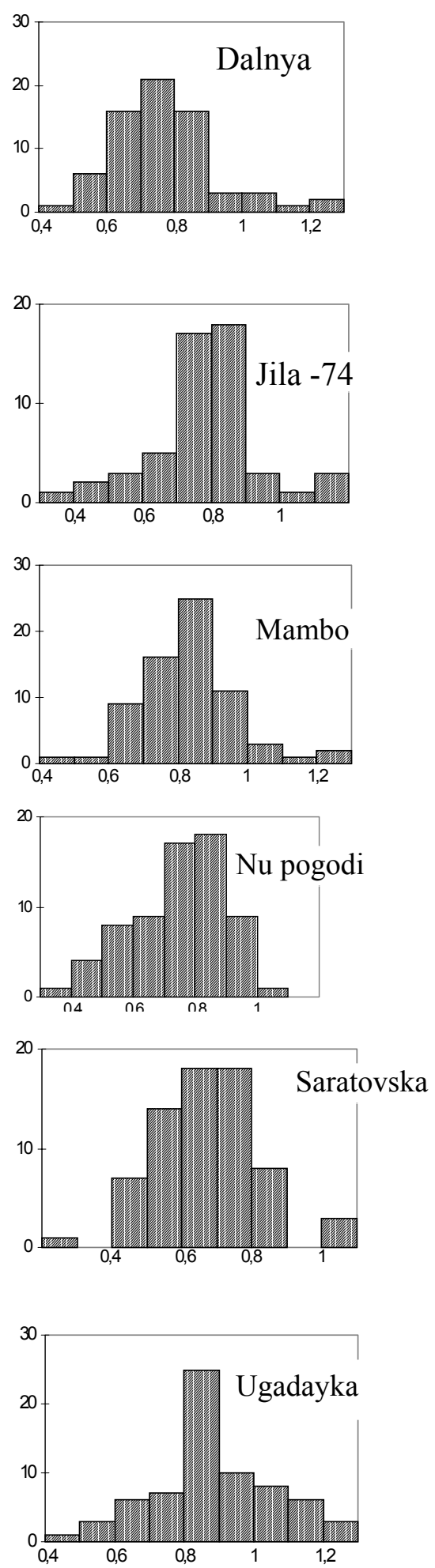
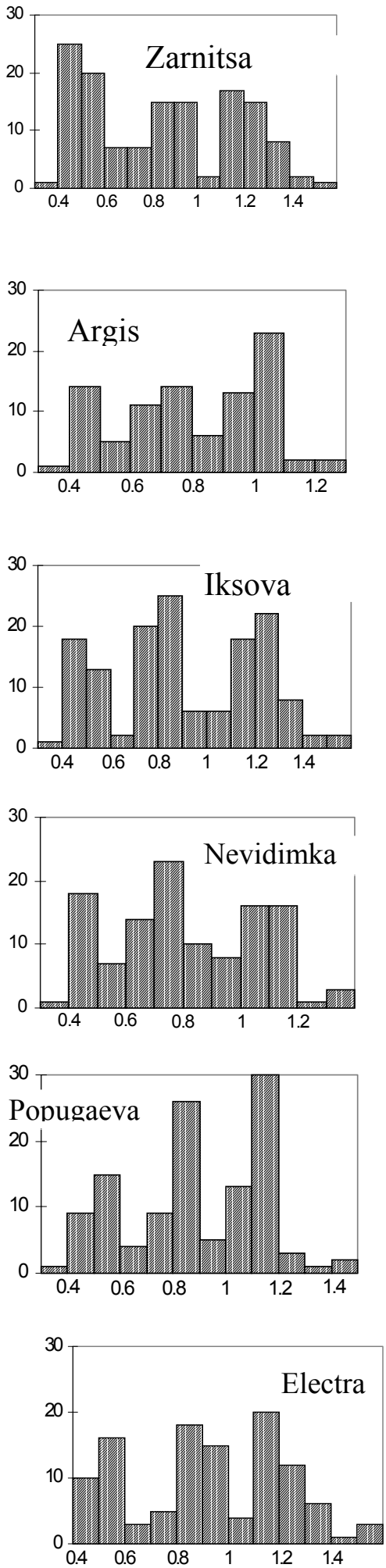

Fig. 2. Histograms of $\mathrm{Cr}_{2} \mathrm{O}_{3}$ content in picroilmenites from different pipes: the left column belongs to Dalnya cluster, the right one to the Zarnitsa cluster of pipes. 
The first type of distribution is dominant for picroilmenites from the southern part of the Daldyn field, the second one was common for pipes of the northern part of the field. The ilmenites from the pipe of the same cluster show both similar pattern of histograms and coincidence of appropriate intervals of $\mathrm{Cr}_{2} \mathrm{O}_{3}$ and $\mathrm{MgO}$, representing corresponding peaks on a histogram. For example, ilmenites from different pipes of Zarnitsa cluster have the following variations of contents $\mathrm{Cr}_{2} \mathrm{O}_{3}$ (1) $0,4-0,6$; (2) $0,8-1,0$; (3) $1,2-1,4$ wt. $\%$, corresponding to three peaks on the histograms. The ilmenites from cluster Malyutka with the analogous tree-peak distribution have different variations of $\mathrm{Cr}_{2} \mathrm{O}_{3}$ contents (1) $0,8-1,0$; (2) $1,15-1,45$; (3) 1,9-2,2 wt. \%, proving their high-chromium composition (see Table).

\section{DISCUSSION}

It was pointed out that picroilmenites from different pipes of the same cluster are practically not distinguishable from each other both in the averaged characteristics of the composition and histograms of distribution of some oxides. The pipes occurring away from the main linearly oriented cluster represent an exception. Identical compositions of picroilmenite from different pipes of the same cluster suggest an important inference on genesis. Uniformity of the composition of ilmenite from the same cluster is due to the existence of the same magmatic chamber for a cluster of pipes. It was assumed that if a relative homogeneity of picroilmenite within a field is due to the common asthenospheric source, the specific composition of picroilmenite for a certain cluster of pipes was created by a magmatic chamber (summary product of asthenosphere and lithosphere sources). If it is correct, geologists would acquire a reliable geological criterion for uniting pipe bodies into clusters, which were formerly distinguished only from subjective considerations of a spatial proximity of pipes. Thus, ilmenite becomes so-called x-ray beam which can be used in analyzing the structure of a kimberlite field.

Marked differences in composition of picroilmenite from kimberlites of the northern and southern parts of the Daldyn field (after magnesium content and histograms of $\mathrm{Cr}_{2} \mathrm{O}_{3}$ distribution) are obviously conditioned by the block heterogeneity of the upper mantle and corresponding local heterogeneity of asthenospheric source.

\section{CONCLUSIONS}

The features of picroilmenite composition distribution in the Daldyn field are as follows:
* Majority of proximal kimberlite bodies (same cluster) share close values of the average contents of $\mathrm{MgO}$ and $\mathrm{Cr}_{2} \mathrm{O}_{3}$ in picroilmenites.

* Picroilmenites of different clusters of pipes differ in the averaged values of $\mathrm{MgO}$ and $\mathrm{Cr} 2 \mathrm{O} 3$ contents.

* Compositions of picroilmenite of different pipes of the Daldyn field produce different types of histograms of $\mathrm{MgO}$ and $\mathrm{Cr}_{2} \mathrm{O}_{3}$ distribution with single peak, two-peak and three-peak patterns. Majority of kimberlite bodies of the same cluster exhibit the same type of histograms.

* The compositions of picroilmenites are most identical when they belong to pipes of the linearly oriented cluster.

* It was proved that picroilmenites of the southern clusters of the Daldyn field (pipes Dalnya and Lenigradska) have heightened contents of $\mathrm{MgO}$ versus those of the northern clusters.

* It was supposed that different magmatic chambers served as the sources of picroilmenite in the pipes of different clusters.

The studies were financially supported by "ALROSA" Corporation and RFBR grant \# 02-05-64793.

\section{REFERENCES}

Ilupin I.P. (1976): New data on heterogeneity of the upper mantle. Doklady AN SSSR, v. 229, \# 4, p. 974-976. (In Russian)

Ilupin, IP., Vaganov V.I., and Prokopchuk B.I (1992)

Kimberlites. Moscow: Nedra. 248 p. (In Russian)

Kostrovitsky, SI. (1986) Geochemical peculiarities of kimberlite minerals. Novosibirsk, Nauka. 264p. (In Russian)

Contact: S.I. Kostrovitsky, PO Box 4019 Irkutsk, Russia, 664033, E-mail: serkost@,igc.irk.ru 